\title{
CSR Case Studies: Identifying Core References with Direct Citation Analysis
}

doi: http://dx.doi.org/10.12775/JCRL.2020.001

\author{
ANDRZEJ Lis \\ The Faculty of Economic Sciences and Management, Nicolaus \\ Copernicus University in Toruń, Poland \\ e-mail: andrzejlis@econ.umk.pl
}

\begin{abstract}
Purpose: The aim of the paper is to identify, through citation analysis, the core references employing case study methodology to explore CSR issues in various organizational contexts. The research process is focused on the following study questions: (1) What are the core references analysing CSR case studies? (2) What are the research contexts of the top rated case studies in CSR?

Methodology: The study employs the method of direct citation analysis, which is categorized among the science mapping, bibliometric methods. As the method of citation analysis favours older publications, which have had more opportunities to receive a higher number of citations, the traditional approach based on identifying the most cited publications is supplemented with the analysis of the normalized number of citations, which mitigates such a bias. The analysis and visualization of findings are supported with VOSviewer software.

Findings: The analysis has identified the core references among case studies exploring corporate social responsibility issues. Then, the identified publications have been explored and their research contexts have been recognized.The core case studies in CSR show their particular interest in such contexts and issues as: (1) heavy industries (e.g. mining and oil industries); (2) supply chains; (3) various types of businesses, including
\end{abstract}




\begin{abstract}
large companies, SMEs, and family businesses; (4) the perspectives of important stakeholders such as governments and NGOs; and recently (5) the food industry.
\end{abstract}

Research and practical implications: Through mapping scientific output of CSR case studies, the paper contributes first and foremost to the development of management theory. It points out the most recognized publications, to be considered as role models for the followers. It may also provide inspiration for further exploration of corporate social responsibility practices with the use of case study methodology.

Originality/value: The uniqueness of the paper derives from the fact that CSR case studies have not been yet mapped as a research field. Moreover, the employment of bibliometric methodology enabling objective analysis of a large number of publications and their attributes, and effective visualization techniques increase value of the study.

Paper type: Review.

Keywords: corporate social responsibility, CSR, case study, bibliometrics, direct citation analysis.

\title{
1. Introduction
}

Case study analysis (Myers, 2010; Rowley, 2002; Strumińska-Kutra \& Koładkiewicz, 2012; Yin, 2010) is found to be a useful methodology for exploring context-embedded management problems (Lis, 2018; Patton \& Appelbaum, 2003). This observation applies as well to the studies of CSR practices, which attract the attention of ranks of scholars cultivating the field. Nevertheless, scientific output of CSR related case studies has not been mapped yet with the use of bibliometrics. Thus, the community of Journal of Corporate Responsibility and Leadership has made attempts to fill the identified gap and contribute to science mapping of the field. Identification and exploration of core references through citation analysis is one of the recommended research lines (Lis, 2019).

The aim of the paper is to identify, through citation analysis, the core references employing case study methodology to explore CSR issues in various organizational contexts. The research process is focused on the following study questions: (1) What are the core references analysing CSR case studies? (2) What are the research contexts of the top rated case studies in CSR? In the remainder of the article, firstly, the method of study and the research sampling process are explained. Secondly, 
the core references of the highest number of received citations are identified. Thirdly, the attribute of the normalized number of citations is used to mitigate the effect of the bias of direct citation analysis towards older publications. Fourthly, the research contexts analysed in the core CSR case studies are discussed.

\section{Method of study}

The study employs the method of direct citation analysis (Boyack \& Klavans, 2010; Smith, 1981), which is categorized among science mapping, bibliometric methods (Klincewicz et al., 2012; Zupic \& Čater, 2015). The analysis and visualization of findings are supported with VOSviewer software (van Eck \& Waltman, 2010, 2020). The attributes of the number of citations, and the normalized number of citations are used as the measures to identify the core references within the research field. As the method of citation analysis favours older publications, which have had more opportunities to receive a higher number of citations, the traditional approach based on identifying the most cited publications is supplemented with the analysis of the normalized number of citations, which mitigates such a bias. As explained in the VOSviewer manual, "[t]he normalized number of citations of a document equals the number of citations of the document divided by the average number of citations of all documents published in the same year and included in the data that is provided to VOSviewer. The normalization corrects for the fact that older documents have had more time to receive citations than more recent documents" (van Eck \& Waltman, 2020, p. 37). Additionally, information about the number of citation links among the publications within the research sample was provided to indicate the strength of relatedness among the analysed references. While conducting analysis, the association strength normalization method and the default settings of VOSviewer were used.

Scopus was the source of bibliometric data in the research sampling process. As of 08 November 2020, the search for the publications containing the phrases 'CSR' or 'corporate social responsibility' in their titles and simultaneously (logical conjunction) the phrase 'case stud*' (with the truncation technique switched on) in titles, keywords and abstracts resulted in 819 items retrieved. No limitations regarding the 
date of publication or a subject area were imposed in order to include the maximum number of relevant publications.

\section{Results presentation}

\subsection{Core references (number of citations)}

819 publications comprising the research sample received in total 13,264 citations. Among them, there are 10 items, which were cited at least 200 times. These core references were published in Journal of Business Ethics (5 items) and Journal of Cleaner Production (2),

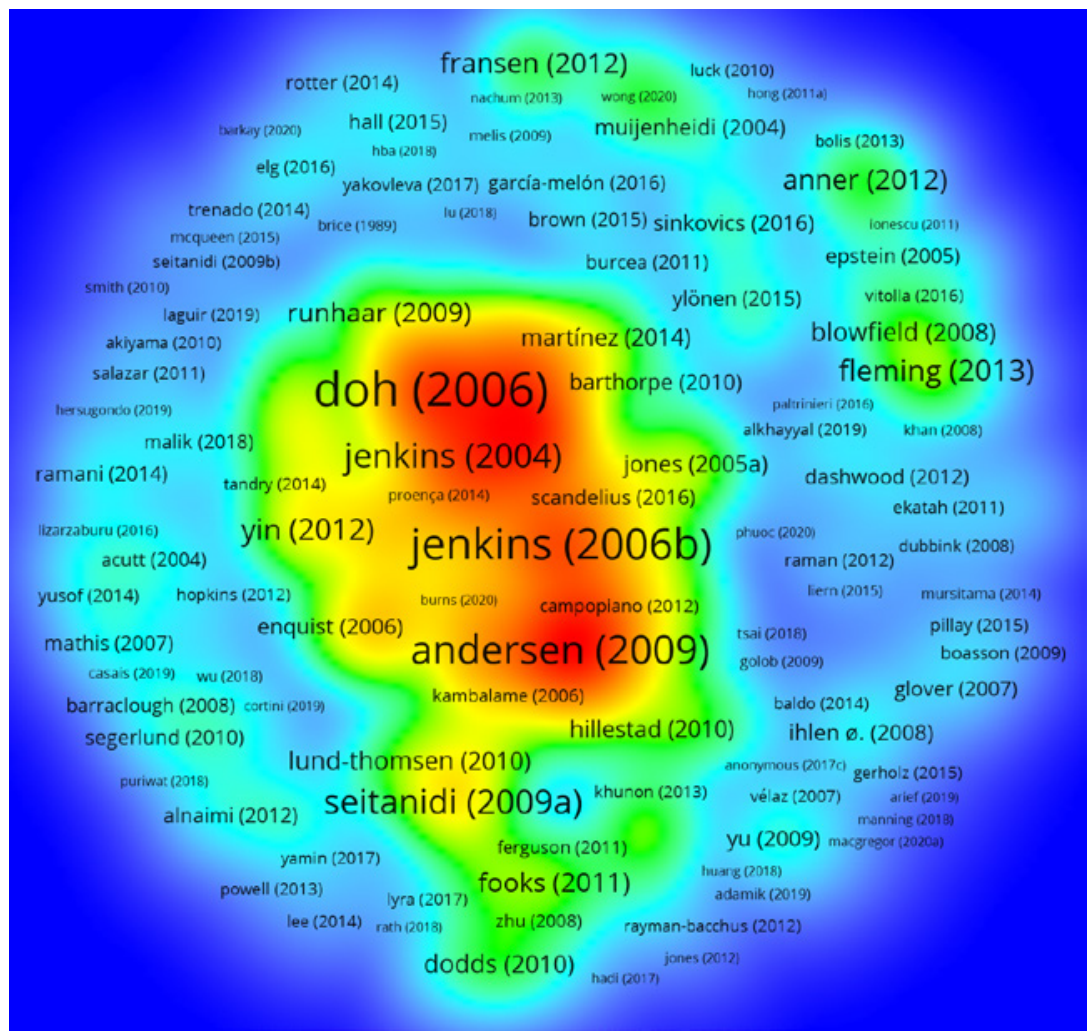

Figure 1. Item density visualization of core references direct citation analysis [weights: citations]

Source: own study based on data retrieved from Scopus (access on 08 November 2020) and analysed with VOSviewer. 
Journal of Management Studies (1), Supply Chain Management: An International Journal (1), and Corporate Social Responsibility and Environmental Management (1). The publications with the highest number of citations are the works by: Doh and Guay (2006), Jenkins and Yakovleva (2006), and Jenkins (2006). In regard to the number of citation links, the top ranked items in the sample are: Maon et al. (2009), Ciliberti et al. (2008), Jenkins and Yakovleva (2006), Murillo and Lozano (2006). The visualization of citation analysis of CSR case studies is displayed in Figure 1 and the detailed catalogue of the core references is listed in Table 2.

Table 1. The top 10 core references among CSR case studies (ranked by the number of citations)

\begin{tabular}{|c|c|c|c|c|c|}
\hline No. & $\begin{array}{l}\text { Author } \\
\text { (date of } \\
\text { publication) }\end{array}$ & Title & Source title & $\begin{array}{l}\text { Citations } \\
{[N]}\end{array}$ & $\begin{array}{l}\text { Links } \\
{[N]}\end{array}$ \\
\hline 1. & $\begin{array}{l}\text { Doh and Guay } \\
\text { (2006) }\end{array}$ & $\begin{array}{l}\text { Corporate social } \\
\text { responsibility, public policy, } \\
\text { and NGO activism in Europe } \\
\text { and the United States: An } \\
\text { institutional-stakeholder } \\
\text { perspective }\end{array}$ & $\begin{array}{l}\text { Journal of } \\
\text { Management } \\
\text { Studies }\end{array}$ & 538 & 16 \\
\hline 2. & $\begin{array}{l}\text { Jenkins and } \\
\text { Jakovleva } \\
(2006)\end{array}$ & $\begin{array}{l}\text { Corporate social } \\
\text { responsibility in the mining } \\
\text { industry: Exploring trends } \\
\text { in social and environmental } \\
\text { disclosure }\end{array}$ & $\begin{array}{l}\text { Journal of } \\
\text { Cleaner } \\
\text { Production }\end{array}$ & 467 & 18 \\
\hline 3. & Jenkins (2006) & $\begin{array}{l}\text { Small business champions } \\
\text { for corporate social } \\
\text { responsibility }\end{array}$ & $\begin{array}{l}\text { Journal of } \\
\text { Business Ethics }\end{array}$ & 434 & 17 \\
\hline 4. & $\begin{array}{l}\text { Andersen and } \\
\text { Skjoett-Larsen } \\
(2009)\end{array}$ & $\begin{array}{l}\text { Corporate social } \\
\text { responsibility in global } \\
\text { supply chains }\end{array}$ & $\begin{array}{l}\text { Supply Chain } \\
\text { Management: } \\
\text { An International } \\
\text { Journal }\end{array}$ & 352 & 10 \\
\hline 5. & $\begin{array}{l}\text { Murillo and } \\
\text { Lozano (2006) }\end{array}$ & $\begin{array}{l}\text { SMEs and CSR: An } \\
\text { approach to CSR in their } \\
\text { own words }\end{array}$ & $\begin{array}{l}\text { Journal of } \\
\text { Business Ethics }\end{array}$ & 299 & 18 \\
\hline 6. & $\begin{array}{l}\text { Ciliberti et al. } \\
\text { (2008) }\end{array}$ & $\begin{array}{l}\text { Investigating corporate } \\
\text { social responsibility in } \\
\text { supply chains: A SME } \\
\text { perspective }\end{array}$ & $\begin{array}{l}\text { Journal of } \\
\text { Cleaner } \\
\text { Production }\end{array}$ & 262 & 19 \\
\hline
\end{tabular}




\begin{tabular}{|c|c|c|c|c|c|}
\hline No. & $\begin{array}{l}\text { Author } \\
\text { (date of } \\
\text { publication) }\end{array}$ & Title & Source title & $\begin{array}{l}\text { Citations } \\
{[N]}\end{array}$ & $\begin{array}{l}\text { Links } \\
{[N]}\end{array}$ \\
\hline 7. & $\begin{array}{l}\text { Maon et al. } \\
\text { (2009) }\end{array}$ & $\begin{array}{l}\text { Designing and implementing } \\
\text { corporate social } \\
\text { responsibility: An integrative } \\
\text { framework grounded in } \\
\text { theory and practice }\end{array}$ & $\begin{array}{l}\text { Journal of } \\
\text { Business Ethics }\end{array}$ & 256 & 26 \\
\hline 8. & $\begin{array}{l}\text { Du and Vieira } \\
\text { (2012) }\end{array}$ & $\begin{array}{l}\text { Striving for legitimacy } \\
\text { through corporate social } \\
\text { responsibility: Insights from } \\
\text { oil companies }\end{array}$ & $\begin{array}{l}\text { Journal of } \\
\text { Business Ethics }\end{array}$ & 226 & 8 \\
\hline 9. & $\begin{array}{l}\text { Seitanidi and } \\
\text { Crane (2009) }\end{array}$ & $\begin{array}{l}\text { Implementing CSR through } \\
\text { partnerships: Understanding } \\
\text { the selection, design } \\
\text { and institutionalisation } \\
\text { of nonprofit-business } \\
\text { partnerships }\end{array}$ & $\begin{array}{l}\text { Journal of } \\
\text { Business Ethics }\end{array}$ & 207 & 4 \\
\hline 10. & Jenkins (2004) & $\begin{array}{l}\text { Corporate social } \\
\text { responsibility and the } \\
\text { mining industry: Conflicts } \\
\text { and constructs }\end{array}$ & $\begin{array}{l}\text { Corporate Social } \\
\text { Responsibility } \\
\text { and } \\
\text { Environmental } \\
\text { Management }\end{array}$ & 201 & 14 \\
\hline
\end{tabular}

Source: own study based on data retrieved from Scopus (access on 08 November 2020) and analysed with VOSviewer.

Doh and Guay (2006) explore the case studies of "global warming, trade in genetically modified organisms and pricing of anti-viral pharmaceuticals in developing countries" to find "that different institutional structures and political legacies in the US and EU are important factors in explaining how governments, NGOs, and the broader polity determine and implement preferences regarding CSR in these two important world regions" (Doh \& Guay, 2006, p. 47). Jenkins and Yakovleva (2006) analyse the maturity of corporate social responsibility programmes reported by the world's largest companies operating in the mining industry. In another work focused on this industry, Jenkins (2004) "examines mining companies reports, revealing the language and constructs used by the mining industry to frame its responsibility to the environment and community and role 
in possible conflicts” (Jenkins, 2004, p. 23). The multiple case study by Jenkins (2006) explores the CSR concept implementation in the context of the UK's sector of small and medium enterprises (SMEs). Andersen and Skjoett-Larsen (2009) discuss social responsibility in global supply chains from the perspective of Ikea, a global furniture manufacturer of the Swedish origin. Murillo and Lozano (2006) analyse the understanding and approaches to CSR represented by Catalan SMEs. Ciliberti et al. (2008) employ the perspective of SMEs to investigate corporate social responsibility in supply chains. Maon et al. (2009) use the multiple case study analysis of Ikea, Phillips and Unilever to support theoretical discussion of the framework integrating both designing and implementation of CSR processes and their key success factors. Du and Vieira (2012) explore business strategies and CSR practices and communication among oil companies aimed at obtaining legitimacy. Seitanidi and Crane (2009) analyse two cases of CSR oriented partnerships between business companies and nonprofit organisations, giving attention to selection of partners, design and institutionalisation of partnerships.

\subsection{Core references (normalized number of citations)}

In order to mitigate the bias of citation analysis towards the earliest publications in the field, which in a natural way have had greater chances to receive more citations, the attribute of the normalized number of citation count is introduced. The top 10 works of the highest normalized number of citations were published in: Journal of Cleaner Production (3 items), Journal of Business Ethics (2) Business and Society (1), Sustainability (Switzerland) (1), Supply Chain Management: An International Journal (1), Family Business Review (1), Extractive Industries and Society (1). The core references are very recent works by Hosseini-Motlagh et al. (2020), Penttilä (2020) and Nazzaro et al. (2020). The visualization of normalized citations analysis of CSR case studies is displayed in Figure 2 and the catalogue of leading references identified with the use of this measure is listed in Table 2. 


\section{Andrzej Lis}

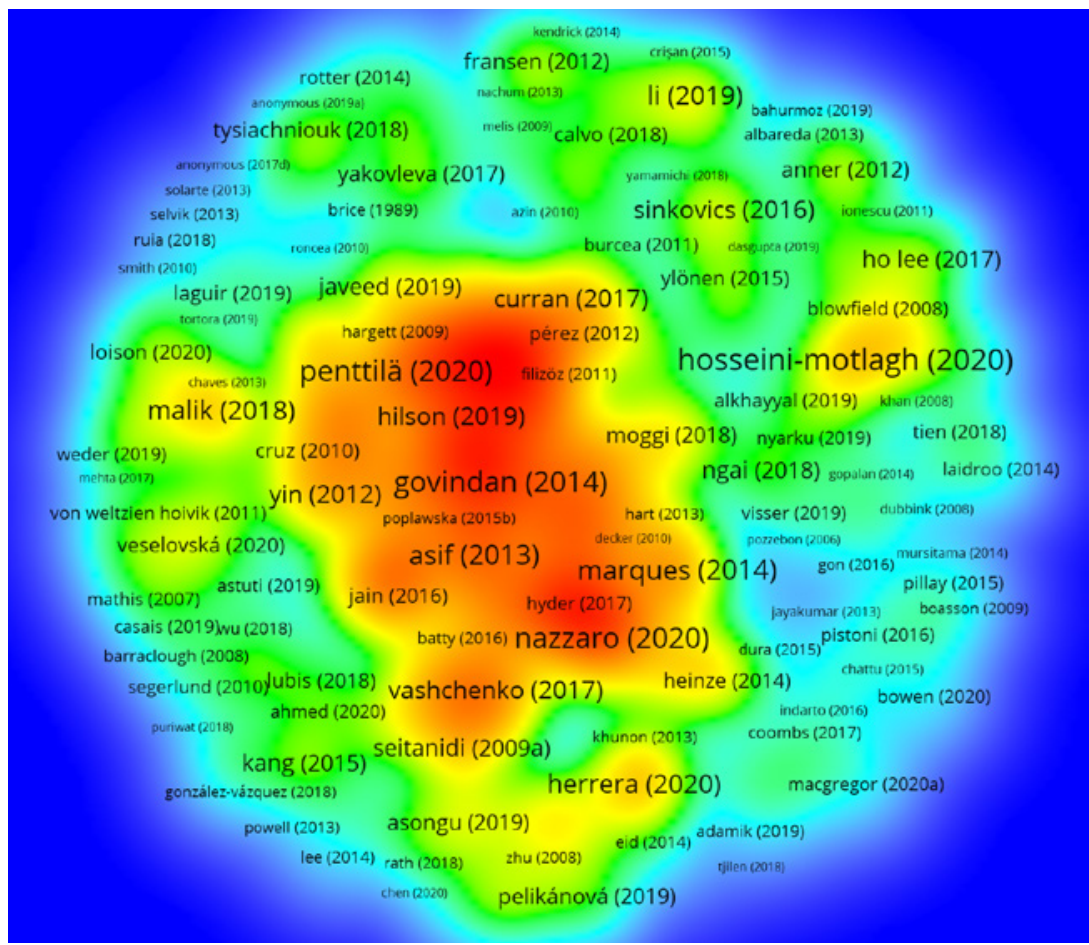

Figure 2. Item density visualization of core references direct citation analysis [weights: normalized citations]

Source: own study based on data retrieved from Scopus (access on 08 November 2020) and analysed with VOSviewer.

Table 2. The top 10 core references among CSR case studies (ranked by the normalized number of citations)

\begin{tabular}{llllll}
\hline No. & $\begin{array}{l}\text { Author } \\
\text { (date of } \\
\text { publication) }\end{array}$ & Title & Source title & $\begin{array}{l}\text { Citations } \\
{[\mathbf{N}]}\end{array}$ & $\begin{array}{l}\text { Normalized } \\
\text { citations }\end{array}$ \\
\hline 1. & $\begin{array}{l}\text { Hosseini- } \\
\text { Motlagh et al. } \\
(2020)\end{array}$ & $\begin{array}{l}\text { Coordination of dual- } \\
\text { function acquisition } \\
\text { price and corporate } \\
\text { social responsibility in } \\
\text { a sustainable closed-loop } \\
\text { supply chain }\end{array}$ & $\begin{array}{l}\text { Journal of } \\
\text { Cleaner } \\
\text { Production }\end{array}$ & 10 & 10.67 \\
& & & & \\
\hline
\end{tabular}




\begin{tabular}{|c|c|c|c|c|c|}
\hline No. & $\begin{array}{l}\text { Author } \\
\text { (date of } \\
\text { publication) }\end{array}$ & Title & Source title & $\begin{array}{l}\text { Citations } \\
{[N]}\end{array}$ & $\begin{array}{l}\text { Normalized } \\
\text { citations }\end{array}$ \\
\hline 2. & Penttilä (2020) & $\begin{array}{l}\text { Aspirational talk in strategy } \\
\text { texts: A longitudinal } \\
\text { case study of strategic } \\
\text { episodes in corporate } \\
\text { social responsibility } \\
\text { communication }\end{array}$ & $\begin{array}{l}\text { Business and } \\
\text { Society }\end{array}$ & 7 & 9.33 \\
\hline 3. & $\begin{array}{l}\text { Nazzaro et al. } \\
(2020)\end{array}$ & $\begin{array}{l}\text { The life cycle of corporate } \\
\text { social responsibility in } \\
\text { agri-food: Value creation } \\
\text { models }\end{array}$ & $\begin{array}{l}\text { Sustainability } \\
\text { (Switzerland) }\end{array}$ & 8 & 9.33 \\
\hline 4. & $\begin{array}{l}\text { Govindan et } \\
\text { al. (2014) }\end{array}$ & $\begin{array}{l}\text { Evaluating the drivers } \\
\text { of corporate social } \\
\text { responsibility in the mining } \\
\text { industry with multi-criteria } \\
\text { approach: A multi- } \\
\text { stakeholder perspective }\end{array}$ & $\begin{array}{l}\text { Journal of } \\
\text { Cleaner } \\
\text { Production }\end{array}$ & 103 & 9.31 \\
\hline 5. & $\begin{array}{l}\text { Asif et al. } \\
\text { (2013) }\end{array}$ & $\begin{array}{l}\text { An integrated management } \\
\text { systems approach } \\
\text { to corporate social } \\
\text { responsibility }\end{array}$ & $\begin{array}{l}\text { Journal of } \\
\text { Cleaner } \\
\text { Production }\end{array}$ & 173 & 8.82 \\
\hline 6. & $\begin{array}{l}\text { Du and Vieira } \\
\text { (2012) }\end{array}$ & $\begin{array}{l}\text { Striving for legitimacy } \\
\text { through corporate social } \\
\text { responsibility: Insights from } \\
\text { oil companies }\end{array}$ & $\begin{array}{l}\text { Journal of } \\
\text { Business } \\
\text { Ethics }\end{array}$ & 226 & 8.05 \\
\hline 7. & $\begin{array}{l}\text { Andersen and } \\
\text { Skjoett-Larsen } \\
\text { (2009) }\end{array}$ & $\begin{array}{l}\text { Corporate social } \\
\text { responsibility in global } \\
\text { supply chains }\end{array}$ & $\begin{array}{l}\text { Supply Chain } \\
\text { Management: } \\
\text { An } \\
\text { International } \\
\text { Journal }\end{array}$ & 352 & 7.98 \\
\hline 8. & $\begin{array}{l}\text { Marques et al. } \\
\text { (2014) }\end{array}$ & $\begin{array}{l}\text { The heterogeneity of family } \\
\text { firms in CSR engagement: } \\
\text { The role of values }\end{array}$ & $\begin{array}{l}\text { Family } \\
\text { Business } \\
\text { Review }\end{array}$ & 171 & 7.87 \\
\hline 9. & $\begin{array}{l}\text { Frederiksen } \\
\text { (2019) }\end{array}$ & $\begin{array}{l}\text { Political settlements, } \\
\text { the mining industry } \\
\text { and corporate social } \\
\text { responsibility in developing } \\
\text { countries }\end{array}$ & $\begin{array}{l}\text { Extractive } \\
\text { Industries and } \\
\text { Society }\end{array}$ & 22 & 7.57 \\
\hline 10. & $\begin{array}{l}\text { Amaeshi et al. } \\
\text { (2016) }\end{array}$ & $\begin{array}{l}\text { Corporate social } \\
\text { responsibility in challenging } \\
\text { and non-enabling } \\
\text { institutional contexts: Do } \\
\text { institutional voids matter? }\end{array}$ & $\begin{array}{l}\text { Journal of } \\
\text { Business } \\
\text { Ethics }\end{array}$ & 64 & 7.42 \\
\hline
\end{tabular}

Source: own study based on data retrieved from Scopus (access on 08 November 2020) and analysed with VOSviewer. 
Comparing and contrasting the lists of top 10 core references ranked by the number of received citations and the normalized number of citations, there are found only two publications included in both rankings (Andersen \& Skjoett-Larsen, 2009; Du \& Vieira, 2012). Among other leading works identified with normalized citations, Hosseini-Motlagh et al. (2020) deal with 'sustainable closed-loop supply chains'. In their paper, “[m]otivated by a real case of dairy industry, the bilateral effects of the acquisition price on both reverse and forward channels are considered through its dual functionality” (Hosseini-Motlagh et al., 2020). Penttilä (2020) employs a longitudinal case study of CSR aspirational communication in strategic management. Nazzaro et al. (2020) discuss corporate social responsibility as a strategy for value creation using the multiple case study of three Italian companies operating in the food industry. Govindan et al. (2014) study the case of drivers for implementing corporate social responsibility in the mining industry in India. Asif et al. (2013) analyse the case studies of top-down and bottom-down approaches to integrating corporate social responsibility programs with other management systems. Marques et al. (2014) explore 12 case studies of Spanish family businesses in search of influence of values and family involvement on engagement of companies in CSR practices. Frederiksen (2019) studies “»political settlements « approach to examining the political effects of corporate social responsibility (CSR) in developing countries” (Frederiksen, 2019, p. 162). He employs the case study of large metal mining companies in Zambia.

\section{Results discussion}

Among the most cited case studies in corporate social responsibility, some interesting trends may be observed. Firstly, heavy industries, characterized by their significant impact on the environment and society, such as the mining (Jenkins, 2004; Jenkins \& Yakovleva, 2006) or oil (Du \& Vieira, 2012) industries attract the attention of researchers. Secondly, CSR in supply chains is found to be a topic of high relevance (Andersen \& Skjoett-Larsen, 2009; Ciliberti et al., 2008). Thirdly, case studies are used to analyse the concept of corporate social responsibility in the context of large, global companies (Andersen \& Skjoett-Larsen, 2009; Maon et al., 2009) and SMEs (Ciliberti et al., 2008; Jenkins, 2006; Murillo \& Lozano, 2006). Fourthly, besides business entities, 
the most cited case studies in CSR employ the perspectives of other important stakeholders such as governments and NGOs (Doh \& Guay, 2006; Seitanidi \& Crane, 2009).

The analysis of core CSR case studies attributed with the highest normalized number of citations confirms the continuing interest of scholars in the mining industry (Frederiksen, 2019; Govindan et al., 2014), the oil industry (Du \& Vieira, 2012), and supply chains (Andersen \& Skjoett-Larsen, 2009; Hosseini-Motlagh et al., 2020). Similarly, both large companies (Andersen \& Skjoett-Larsen, 2009; Frederiksen, 2019) and family businesses (Marques et al., 2014) remain the contexts of case studies in CSR issues. A growing interest in corporate social responsibility practices in the food industry (Hosseini-Motlagh et al., 2020; Nazzaro et al., 2020) is a new trend, observed in very recent publications.

The results of the study go along with the findings from the research profiling study by Lis (2019), which identified mining and food industries among the sectors attracting attention of the researchers exploring CSR issues with the use of case study methodology. Similarly, the variety of contexts regarding the company type including large companies, SMEs and family businesses identified through general research profiling is confirmed by the examples of the most cited references recognized with the use of direct citation analysis.

In response to the first study question, the analysis has identified the core references among case studies exploring corporate social responsibility issues. The publications with the highest number of citations are the works by: Doh and Guay (2006), Jenkins and Yakovleva (2006), and Jenkins (2006). In regard to the number of citation links, the top ranked items in the sample are: Maon et al. (2009), Ciliberti et al. (2008), Jenkins and Yakovleva (2006), Murillo and Lozano (2006). The core references with the highest normalized number of citations are very recent works by Hosseini-Motlagh et al. (2020), Penttilä (2020), and Nazzaro et al. (2020). In response to the second study questions, the research contexts of CSR case studies have been identified. The core case studies in CSR show their particular interest in such contexts and issues as: (1) heavy industries (e.g. mining and oil industries); (2) supply chains; (3) various types of businesses, including large companies, SMEs, and family businesses; (4) the perspectives of important stakeholders such as governments and NGOs; and recently (5) the food industry. 


\section{Conclusions}

The analysis has identified the core references among case studies exploring corporate social responsibility issues. Then, the identified publications have been explored and their research contexts have been recognized. The uniqueness of the paper derives from the fact that CSR case studies have not been yet mapped as a research field. Moreover, the employment of bibliometric methodology enabling objective analysis of a large number of publications, and their attributes, and effective visualization techniques increase the value of the study. Through mapping scientific output of CSR case studies, the paper contributes first and foremost to the development of management theory. It highlights the core references among CSR case studies and identifies research contexts they are embedded in. Thus, it may provide inspiration for further exploration of corporate social responsibility practices with case study methodology. Summing up, the paper contributes to the efforts undertaken by the community of Journal of Corporate Responsibility and Leadership to explore and map the case studies in corporate social responsibility, and continuation of bibliometric studies in the field is recommended.

While analyzing and discussing research findings, limitations of the study should be taken into account. Firstly, as the only one research method (direct citation analysis) was employed, the lack of triangulation in methodology is worth mentioning. Secondly, inherent weaknesses of citation analysis (cf. Smith, 1981) need to be considered. Thirdly, only one source of data (Scopus) was used in the research sampling process, which makes the sample vulnerable to some biases of the database (e.g. bias towards publications written in English). To overcome the identified limitations, in further studies, it is recommended to: (1) replicate the citation analysis based on another sources of bibliometric data, (2) triangulate the findings from direct citation analysis through employing other bibliometric methods e.g. co-citation analysis and bibliographic coupling to explore more thoroughly core references, and co-word analysis to comprehensively map the research contexts (3) follow bibliometric analyses with a 'deep dive' into CSR case studies with the use of systematic literature review methodology. 


\section{References}

Amaeshi, K., Adegbite, E., \& Rajwani, T. (2016). Corporate social responsibility in challenging and non-enabling institutional contexts: Do institutional voids matter? Journal of Business Ethics, 134(1), 135-153. https://doi.org/10.1007/ s10551-014-2420-4

Andersen, M., \& Skjoett-Larsen, T. (2009). Corporate social responsibility in global supply chains. Supply Chain Management: An International Journal, 14(2), 75-86. https://doi.org/10.1108/13598540910941948

Asif, M., Searcy, C., Zutshi, A., \& Fisscher, O. A. M. (2013). An integrated management systems approach to corporate social responsibility. Journal of Cleaner Production, 56, 7-17. https://doi.org/10.1016/j.jclepro.2011.10.034

Boyack, K. W., \& Klavans, R. (2010). Co-citation analysis, bibliographic coupling, and direct citation: Which citation approach represents the research front most accurately? Journal of the American Society for Information Science and Technology, 61(12), 2389-2404. https://doi.org/10.1002/asi.21419

Ciliberti, F., Pontrandolfo, P., \& Scozzi, B. (2008). Investigating corporate social responsibility in supply chains: A SME perspective. Journal of Cleaner Production, 16(15), 1579-1588. https://doi.org/10.1016/j.jclepro.2008.04.016

Doh, J. P., \& Guay, T. R. (2006). Corporate social responsibility, public policy, and NGO activism in Europe and the United States: An institutional-stakeholder perspective. Journal of Management Studies, 43(1), 47-73. https://doi.org/10.1111/j.1467-6486. 2006.00582.x

Du, S., \& Vieira, E. T. (2012). Striving for legitimacy through corporate social responsibility: Insights from oil companies. Journal of Business Ethics, 110(4), 413-427. https://doi.org/10.1007/s10551-012-1490-4

Frederiksen, T. (2019). Political settlements, the mining industry and corporate social responsibility in developing countries. Extractive Industries and Society, 6(1), 162-170. https://doi.org/10.1016/j.exis.2018.07.007

Govindan, K., Kannan, D., \& Shankar, K. M. (2014). Evaluating the drivers of corporate social responsibility in the mining industry with multi-criteria approach: A multistakeholder perspective. Journal of Cleaner Production, 84(1), 214-232. https:// doi.org/10.1016/j.jclepro.2013.12.065

Hosseini-Motlagh, S. M., Ebrahimi, S., \& Zirakpourdehkordi, R. (2020). Coordination of dual-function acquisition price and corporate social responsibility in a sustainable closed-loop supply chain. Journal of Cleaner Production, 251. https:// doi.org/10.1016/j.jclepro.2019.119629

Jenkins, H. (2004). Corporate social responsibility and the mining industry: Conflicts and constructs. Corporate Social Responsibility and Environmental Management, 11(1), 23-34. https://doi.org/10.1002/csr.50

Jenkins, H. (2006). Small business champions for corporate social responsibility. Journal of Business Ethics, 67(3), 241-256. https://doi.org/10.1007/s10551-006-9182-6

Jenkins, H., \& Yakovleva, N. (2006). Corporate social responsibility in the mining industry: Exploring trends in social and environmental disclosure. Journal of Cleaner Production, 14(3-4), 271-284. https://doi.org/10.1016/j.jclepro.2004. 10.004

Klincewicz, K., Żemigała, M., \& Mijal, M. (2012). Bibliometria w zarzq̨dzaniu technologiami i badaniami naukowymi. Ministerstwo Nauki i Szkolnictwa Wyższego. 
Lis, A. (2018). Profiling and mapping the contexts of the case study research in Business, Management and Accounting. International Journal of Contemporary Management, 17(1), 179-196. https://doi.org/10.4467/24498939ijcm.18.010.8389

Lis, A. (2019). Case study methodology in research on corporate social responsibility: General publication profiling and identifying research contexts. Journal of Corporate Responsibility and Leadership, 6(2), 7-28. https://doi.org/10.12775/ JCRL.2019.005

Maon, F., Lindgreen, A., \& Swaen, V. (2009). Designing and implementing corporate social responsibility: An integrative framework grounded in theory and practice. Journal of Business Ethics, 87(SUPPL. 1), 71-89. https://doi.org/10.1007/s10551 -008-9804-2

Marques, P., Presas, P., \& Simon, A. (2014). The heterogeneity of family firms in CSR engagement: The role of values. Family Business Review, 27(3), 206-227. https:// doi.org/10.1177/0894486514539004

Murillo, D., \& Lozano, J. M. (2006). SMEs and CSR: An approach to CSR in their own words. Journal of Business Ethics, 67(3), 227-240. https://doi.org/10.1007/ s10551-006-9181-7

Myers, M. D. (2010). Case study research. In M. Frenz, K. Nielsen, \& G. Walters (Eds.), Research Methods in Management (pp. 227-248). Sage.

Nazzaro, C., Stanco, M., \& Marotta, G. (2020). The life cycle of corporate social responsibility in agri-food: Value creation models. Sustainability (Switzerland), 12(4). https://doi.org/10.3390/su12041287

Patton, E., \& Appelbaum, S. H. (2003). The case for case studies in management research. Management Research News, 26(5), 60-71. https://doi.org/10.1108/0140 9170310783484

Penttilä, V. (2020). Aspirational talk in strategy texts: A longitudinal case study of strategic episodes in corporate social responsibility communication. Business and Society, 59(1), 67-97. https://doi.org/10.1177/0007650319825825

Rowley, J. (2002). Using case studies in research. Management Research News, 25(1), 16-27. https://doi.org/10.1108/01409170210782990

Seitanidi, M. M., \& Crane, A. (2009). Implementing CSR through partnerships: Understanding the selection, design and institutionalisation of nonprofit-business partnerships. Journal of Business Ethics, 85(SUPPL. 2), 413-429. https://doi.org/ 10.1007/s10551-008-9743-y

Smith, L. C. (1981). Citation analysis. Library Trends, 30(1), 83-106.

Strumińska-Kutra, M., \& Koładkiewicz, I. (2012). Studium przypadku. In D. Jemielniak (Ed.), Badania jakościowe: Metody i narzędzia (Vol. 2) (pp. 1-40). PWN.

van Eck, N. J., \& Waltman, L. (2010). Software survey: VOSviewer, a computer program for bibliometric mapping. Scientometrics, 84(2), 523-538. https://doi. org/10.1007/s11192-009-0146-3

van Eck, N. J., \& Waltman, L. (2020). VOSviewer Manual. https://www.vosviewer.com/ documentation/Manual_VOSviewer_1.6.15.pdf

Yin, R. K. (2010). Designing case studies. In M. Frenz, K. Nielsen, \& G. Walters (Eds.), Research Methods in Management (pp. 185-226). Sage.

Zupic, I., \& Čater, T. (2015). Bibliometric methods in management and organization. Organizational Research Methods, 18(3), 429-472. https://doi. org/10.1177/1094428114562629 